\title{
New and little-known species of Chthoniidae and Neobisiidae (Pseudoscorpiones, Arachnida) from the Movile Cave in southern Dobrogea, Romania
}

\author{
Božidar P.M. Ćurčć, ${ }^{1}$ George O. Poinar, Jr. ${ }^{2}$ \& Serban M. Sarbu ${ }^{3}$ \\ ${ }^{1}$ Institute of Zoology, Faculty of Science (Biology), University of Belgrade, Studentski Trg 16, 11000 \\ Belgrade, Yugoslavia; ${ }^{2}$ Department of Entomology, University of California, Berkeley, California 94720 , \\ U.S.A.; "'Emil Racovita"' Speleological Institute, Str. Frumoasa 11, 78114 Bucharest, Romania*
}

Keywords: Cave fauna, taxonomy, biogeography, evolution, pseudoscorpions, Chthoniidae, Neobisiidae, Chthonius, Roncus, Neobisium, new species

\begin{abstract}
Two species of Roncus L. Koch, 1873 (Neobisiidae), new to science ( $R$. ciobanmos $\mathrm{n}$. sp. and $R$. dragobete $\mathrm{n}$. sp.), and one species of Neobisium Chamberlin, $1930[N$. (N). biharicum Beier, 1939], collected in the Movile Cave, southern Dobrogea, Romania, have been described, diagnostic characters illustrated, and their geographic distribution analyzed. In addition, the description of Chthonius (Chthonius) monicae Boghean, 1989 (Chthoniidae), otherwise known only from two females, has been amended. The possible relationships of these species are discussed in view of the importance of some diagnostic characters and of the evolution of their cave habitat.
\end{abstract}

\section{Résumé}

Deux nouvelles espèces du genre Roncus L. Koch, 1873 (Neobisiidae), ainsi qu'une espèce du genre Neobisium Chamberlin, 1930 [N. (N.) biharicum Beier, 1939], recueillies dans la grotte Movile en Dobroudja méridionale, Roumanie, sont décrites, leur caractères diagnostiques sont illustrés, et leur répartition est présentée. Une description supplémentaire de Chthonius (Chthonius) monicae Boghean, 1989 (Chthoniidae), est aussi fournie. Les affinités possibles des taxa étudiés sont discutées compte tenu de l'importance de quelques caractères diagnostiques, ainsi que de l'évolution de leur habitat souterrain.

\section{Introduction}

Eleven species of Chthonius C. L. Koch, 1843 (subgenus Chthonius) (Chthoniidae), are presently recorded for Romania, viz.: Chtnonius (C.) caver- narum Ellingsen, 1909; C. (C.) diophthalmus Daday, 1888; C. (C.) heterodactylus Tömösváry, 1882; C. (C.) irregularis brevis Cîrdei, Bulimar \& Malcoci, 1967; C. (C.) jonicus Beier, 1931; C. (C.) leruthi Beier, 1939; C. (C.) monicae Boghean, 1989; C. (C.) motasi Dumitresco \& Orghidan, 1964; C. (C.) orthodactylus (Leach, 1817); C. (C.) submontanus Beier, 1963; and C. (C.) tenuis L. Koch, 1873 (Ionescu, 1936; Beier, 1963; Cîrdei et al., 1967; Boghean, 1989; Harvey, 1991). Of these, only four are endemic: $C$. (C.) irregularis brevis (from Masivul Repedea, near Iaşi), $C$. (C.) leruthi (from Iara, near Turda), $C$. (C.) monicae (from a cave in Dobrogea), and $C$. $(C$.$) motasi (from caves in$ northern, central, and southern Dobrogea).

Three representatives of Roncus L. Koch, 1873 (Neobisiidae) are presently known from Romania: $R$. lubricus L. Koch, 1873; $R$. alpinus L. Koch, 1873; and $R$. transsilvanicus Beier, 1928 (Cîrdei et al., 1967; Harvey, 1991). The presence of $R$. lubricus in Romania is doubtful since this species is considered to be distributed only in northeastern North America and western Europe (Gardini, 1983; Curčcć et al., 1992); moreover, $R$. alpinus occurs in France, Italy, Switzerland, Austria, and Slovenia (Beier, 1963; Curčić, 1988a) but its presence in Romania (Cîrdei et al., 1967) is questionable, as was already noted by Harvey (1991). The occurrence of $\boldsymbol{R}$. transsilvanicus in Romania was subsequently confirmed by Beier (1963) and Harvey (1991). The distribution range of this species ex-

\footnotetext{
* Current address: Department of Biological Sciences, University of Cincinnati, Cincinnati, Ohio 45221-0006, U.S.A.
} 
tends from Czechoslovakia and Poland in the north-west as far as Ukraine in the south-east.

As far as Neobisium Chamberlin, 1930 (subgenus Neobisium) (Neobisiidae) is concerned, the majority of its representatives from Romania are widespread in other European countries. These are: Neobisium ( $N$.$) blothroides 'Tömösváry, 1882); N$. (N.) brevidigitatum (Beier, 1928); N. (N.) carcinoides (Hermann, 1804) [ $=N$. muscorum (Leach, 1817)], N. (N.) carpaticum Beier, 1935; N. (N.) cephalonicum (Daday, 1888); $N$. (N.) crassifemoratum (Beier, 1928); N. (N.) erythrodactylum (L. Koch, 1873); N. (N.) fuscimanum (C. L. Koch, 1843); N. (N.) macrodactylum (Daday, 1888); N. (N.) minimum (Beier, 1928); N. (N.) polonicum Rafalski, 1936; N. (N.) reitteri (Beier, 1928); and $N$. (N.) sylvaticum (C. L. Koch, 1843) (Harvey, 1991). The presence of $N$. (N.) distinctum (Beier, 1928) in Romania is questionable (Cîrdei et al., 1967; Harvey, 1991). Only four species are endemic to the area: $N$. (N.) biharicum Beier, 1939 (from the Bihor area); N. (N.) bucegicum Beier, 1964 (from the Bucegi Mts.); N. (N.) dolicodactylum latum Cîrdei, Bulimar \& Malcoci, 1967 (from Masivul Repedea, near Iaşi); and $N$. (N.) granulosum Beier, 1939 (from Sebeş, Alba) (Cîrdei et al., 1967; Beier, 1963; Harvey, 1991).

During the biological investigations of the Movile Cave in southern Dobrogea, Romania, the third author collected four species of pseudoscorpions belonging to three genera: Chthonius $(C$.) monicae, Roncus ciobanmos $\mathrm{n}$. sp., $R$. dragobete $\mathrm{n}$. sp., and Neobisium (N.) biharicum. The three former species are sympatric relicts, endemic to the area. The fourth species, $N$. (N.) biharicum, is epigean and its presence in the Movile Cave is accidental.

It is worth mentioning that the Movile Cave was discovered accidentally in 1986, when an artificial shaft intercepted a low cave passage. The richness of the terrestrial troglobitic community in this cave was surprising. Of the 29 species of troglobites, 21 appeared to be new to science (Sarbu, 1991; Sarbu \& Popa, 1992); this number is likely to increase, due to subsequent investigations.

The aim of the present paper is to present a redescription of $C$. (C.) monicae, so far known only from two females; to describe the new species of
Roncus; and to offer additional details on the external morphology of $N$. (N.) biharicum. Furthermore, some taxonomic and biogeographic features of these species are discussed in view of the evolution of their underground habitat.

All pseudoscorpion specimens under study were mounted on slides in Swan's fluid (gum chloral medium) and deposited in the collections of the Institute of Zoology, Faculty of Science (Biology), University of Belgrade, Belgrade, Yugoslavia (FSB); the Museum "Grigore Antipa", Bucharest, Romania (MGAB); and the Department of Entomology (Arachnida \& Myriapoda), National Museum of Natural History, Smithsonian Institution, Washington, U.S.A. (USNM).

All abbreviations of setal names are in accordance with Beier (1963).

\section{Descriptive part}

\section{CHTHONIIDAE Daday, 1888}

Chthonius (Chthonius) monicae Boghean, 1989 (Figs. 1-13; Table I)

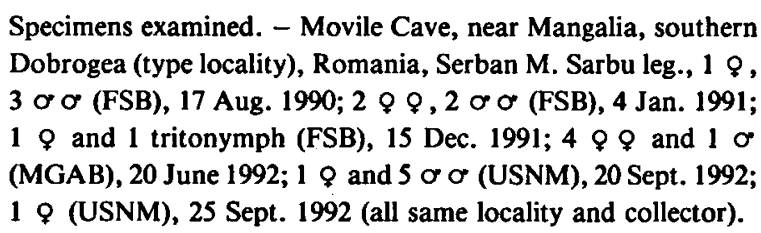

Description (amended). - Epistome not developed; small chitinous points on anterior margin of carapace between the two median and anterior setae (Figs. 1, $7 \&$ 10). Neither eyes nor eye spots are developed. Carapace somewhat longer than broad (Table I); 4 long setae along anterior margin of carapace, 6 in the ocular row, 4 in the median row, 2 in the intermediary row, and 2 (rarely 3 ) setae in the posterior row. (Only in a single female, an additional microseta is borne lateral to the right posterior seta; Fig. 1.) Preocular microsetae: one microseta in each preocular recess (Boghean, 1989) or without microsetae (in presently examined specimens; see also Fig. 1 in Boghean, 1989). Setal formula: $4+6+4+2+2=18$ setae (rarely: $4+$ $6+4+2+3=19$ setae) (not 20, as noted by Boghean, 1989). 

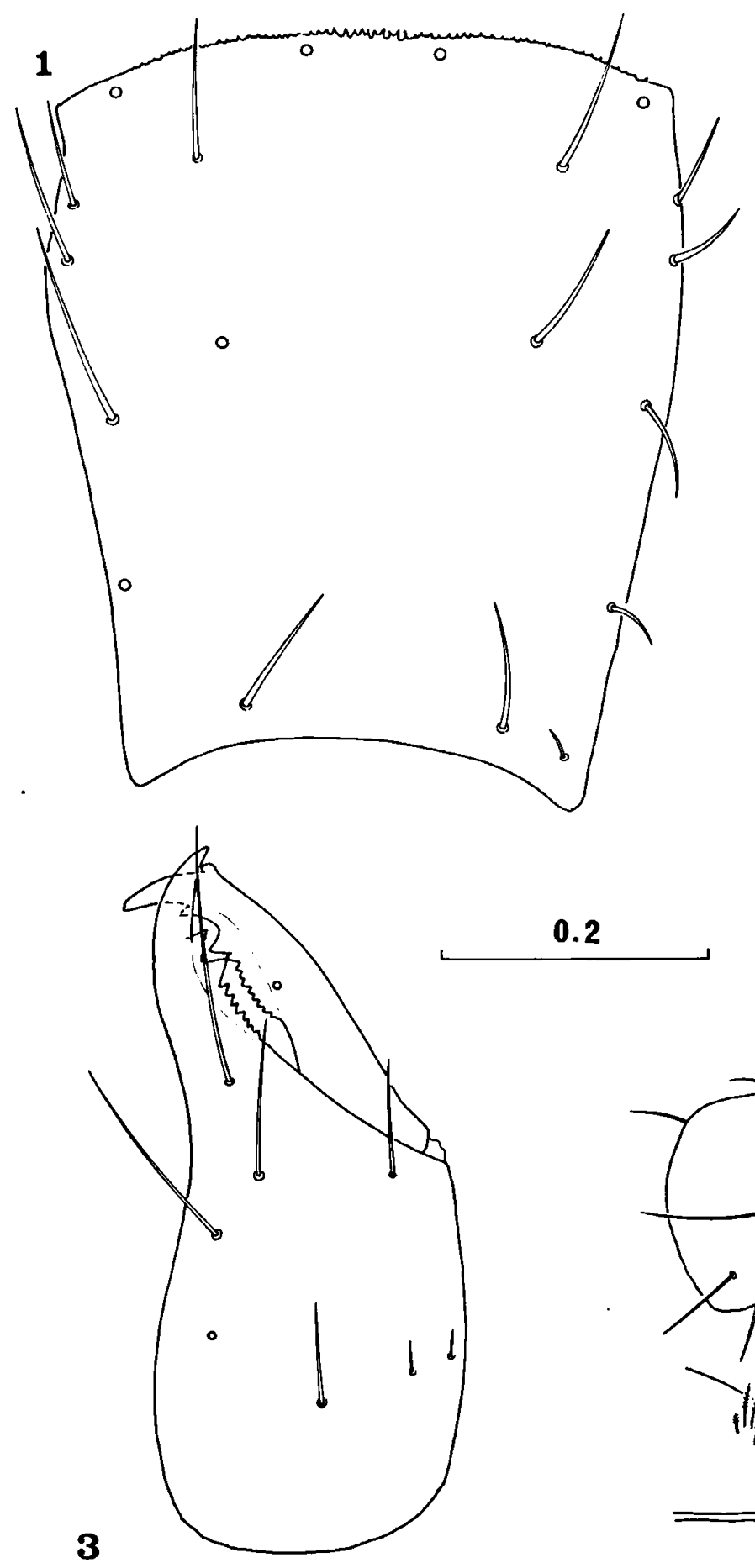

0.2
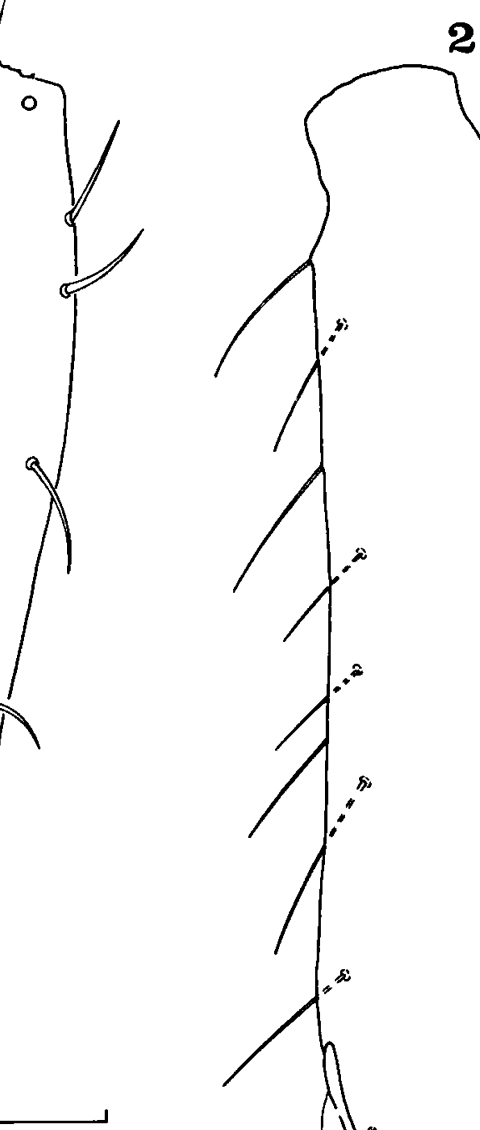

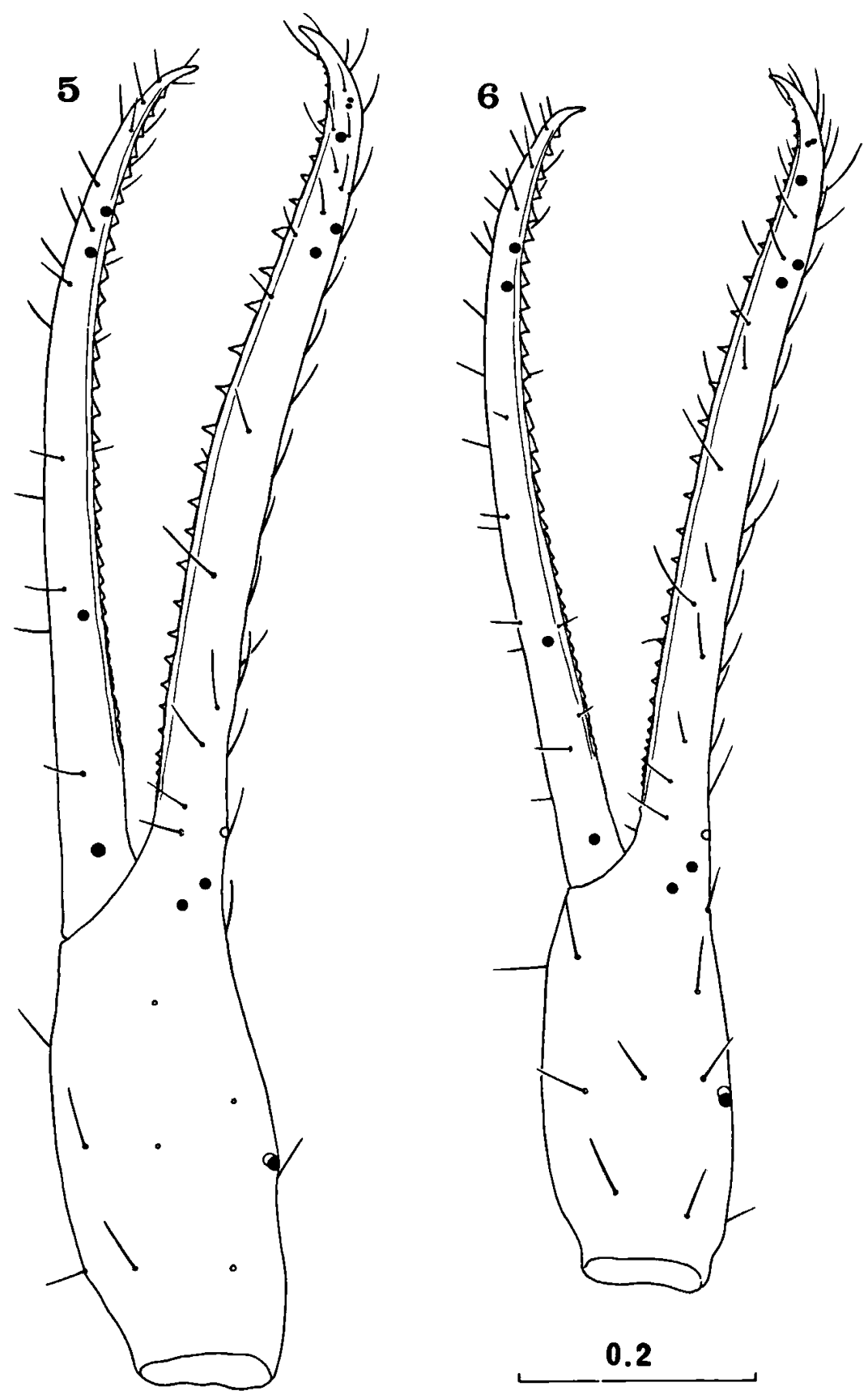

Figs. 5-6. Chthonius (Chthonius) monicae Boghean, 1989, from the Movile Cave, Romania: 5, pedipalpal chela, $९$ (FSB); 6, pedipalpal chela, $O$ (FSB). Scale in $\mathrm{mm}$.

Tergite I with 4 (rarely 2 or 3 ) setae, tergites II-IV each with 4 setae, tergites V-IX each with 6 setae, tergite $X$ with 4 setae. Male genital area: sternite II with 10 or 11 setae in the form of a triangle (of these, 4 setae along posterior margin), sternite
III with 3 suprastigmatic microsetae on each side, 9 posterior setae, and 6 or 7 setae along each side of a median groove. Sternite IV with 7 setae and 3 suprastigmal microsetae on each side. Female genital area: sternite II with $8-10$ setae in the form of 
a triangle; sternite III with 7 or 8 posterior setae (5 according to Boghean, 1989) and 3 suprastigmatic microsetae on either side; sternite IV with 7 marginal setae and 3 small setae along each stigmatic plate. In both sexes, sternites $\mathrm{V}-\mathrm{X}$ each with 6 (rarely 7) setae.

Galea small and rounded (Figs. 3, $9 \& 13$ ); 5 (in tritonymph) or 6 (rarely 5 in adults) long setae on cheliceral palm, and 1 long seta on movable cheliceral finger. Flagellum with 10 or 11 blades, characteristic of the genus Chthonius. Cheliceral dentition as in Figs. 3, 9 \& 13; movable chelal finger with a distal isolated tooth; teeth on both cheliceral fingers diminish in size proximally.

Apex of pedipalpal coxa with 2 long setae. Fixed chelal finger with a total of 20 teeth in tritonymph and 28-30 in adults (26 according to Boghean, 1989); distal and median teeth triangular, pointed and interspaced, the most proximal teeth rounded, low and closely set. Movable chelal finger with 26 teeth in tritonymph and 33-34 in adults (20 according to Boghean, 1989); distal teeth asymmetrical (retroconical) and only slightly interspaced, proximal teeth low, rounded, and closely set (Figs. 5, 6 $\& 11$ ). One denticle in tritonymph and 3-4 in adults distal to $d s$. Pedipalpal femur longer than carapace, chelal fingers considerably longer than chelal palm; fixed chelal finger somewhat longer than movable chelal finger. Shape of pedipalpal femur and tibia presented in Figs. 2, $8 \& 12$, and form of chelal fingers as illustrated in Figs. $5,6 \& 11$.

Trichobothriotaxy (adults; Figs. $5 \& 6$ ): $i b$ and $i s b$ on middle of chelal palm on dorsal side. Setae et-est-it in distal finger half, ist-est-eb on finger base. Tritonymphal trichobothriotaxy as in Fig. 11.

Coxa II with 9 or 10 spines in tritonymph and $8-10$ in adults (6 spines according to Boghean, 1989), coxa III with 5 or 6 spines in tritonymph and 4-6 in adults (Fig. 4). Intercoxal tubercle with 2 small setae (Fig. 4). Leg IV: tibia, basitarsus, and telotarsus each with a long tactile seta.

For morphometric ratios and linear measurements of various structures, see Table I.

Distribution. - Endemic species of southern Dobrogea, Romania (Movile Cave).
Remarks. $-C$. (C.) monicae is easily distinguished from $C$. (C.) bogovinae Curčić, 1972, from eastern Serbia, Yugoslavia, in the dentition of the movable chelal finger (median teeth retroconical and asymmetrical vs. median teeth pointed, triangular, and symmetrical), the presence or absence of denticles distal to $d s$ (present vs. absent), the length of the pedipalpal femur of females $(0.68-0.75 \mathrm{~mm}$ vs. $1.00-1.13 \mathrm{~mm})$ and males $(0.63-0.73 \mathrm{~mm}$ vs. $0.90-0.98 \mathrm{~mm})$, the length of the chelal finger of females $(0.68-0.795 \mathrm{~mm}$ vs. $0.88-1.01 \mathrm{~mm})$ and males $(0.64-0.73 \mathrm{~mm}$ vs. $0.85-1.02 \mathrm{~mm}$ ) (see also Curčić, 1972a).

In addition, $C$. (C.) monicae differs considerably from C. (C.) iugoslavicus Curčić, 1972, from southeastern Serbia, Yugoslavia, in number of setae on carapace (18 vs. 20 ), lateral setae in the posterior carapace row (absent vs. present), ratio of pedipalpal femur length to carapace length of females (1.28-1.49 vs. $1.53-1.76)$, ratio of chelal finger length to chelal palm length of females (1.75-2.15 vs. 1.67-1.74), length of femur IV $(0.62-0.70 \mathrm{~mm}$ vs. $0.50-0.60 \mathrm{~mm}$ ), shape of the proximal teeth of the movable chelal finger (low and rounded vs. forming a basal lamella) (see also Curčić, 1972a, 1972b, 1988a, 1988b).

However, C. (C.) troglodites Redikorzev, 1928, and C. (C.) cavophilus Hadži, 1939, both from Bulgarian caves, are phenetically most similar to $C$. (C.) monicae. From C. (C.) troglodites, C. (C.) monicae differs in carapace setation (20 vs. 18 setae), carapace length $(0.60-0.72 \mathrm{~mm}$ vs. $0.425-$ $0.535 \mathrm{~mm})$, pedipalpal femur length $(1.12-1.18 \mathrm{vs}$. 0.63-0.75 mm), pedipalpal femur length to breadth ratio $(7.30-11.20$ vs. $5.21-6.08)$, and pedipalpal chela length (1.46-1.53 $\mathrm{mm}$ vs. $0.945-1.165 \mathrm{~mm}$ ). The distinctions between $C$. $(C$.) monicae and $C .(C$.$) cavophilus are manifested by$ the setation of the posterior carapace row (2 long setae vs. 2 long and 2 short setae), by the presence/absence of eyes (absent vs. present), by the presence/absence of small teeth distal to $d s$ (present vs. absent), by the pedipalpal chela length of males $(0.945-1.02 \mathrm{~mm}$ vs. $0.80 \mathrm{~mm})$, and by the pedipalpal chela length to breadth ratio $(5.82-6.50$ vs. 5.30) (see also Redikorzev, 1928; Hadži, 1939). Interestingly, $C .(C$.$) monicae exhibits variation$ 

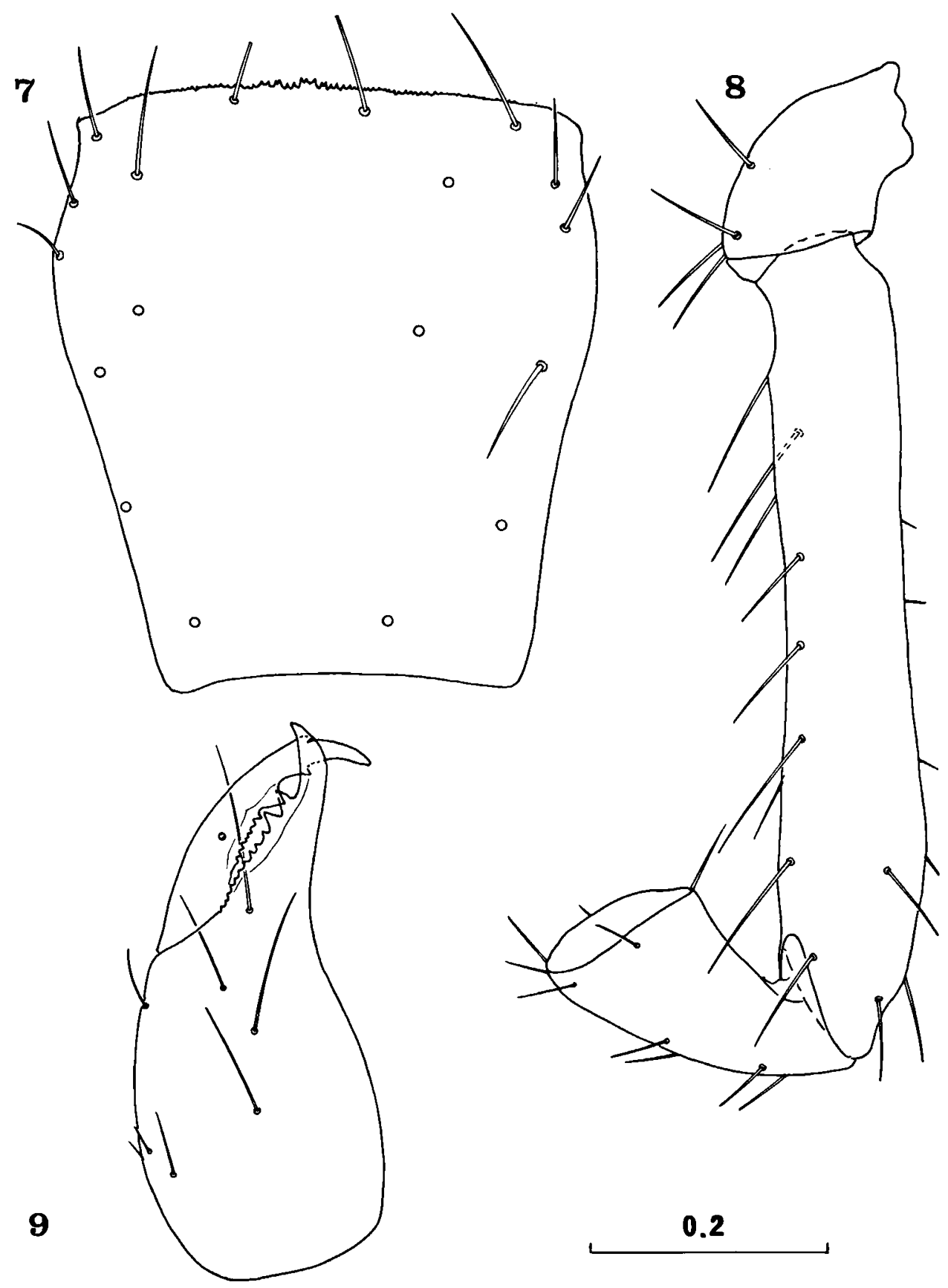

Figs. 7-9. Chthonius (Chthonius) monicae Boghean, ơ (FSB), from the Movile Cave, Romania: 7, carapace; 8, pedipalpal trochanter, femur, and tibia; 9, chelicera. Scale in $\mathrm{mm}$.

in the number of posterior carapace setae (2, rarely 3 ), in the number and position of setae on tergite I (4, rarely 2 or 3 ), and in the presence/absence of preocular microsetae (present or absent). It should be noted that in the case of fewer setae on tergite I, it is always the left lateral seta (when only 3 tergal setae remain), or both lateral setae (when only 2 tergal setae remain), that are missing. The pronounced variation in number of carapacal and tergal setae was also noted in other cave pseudoscorpions from 

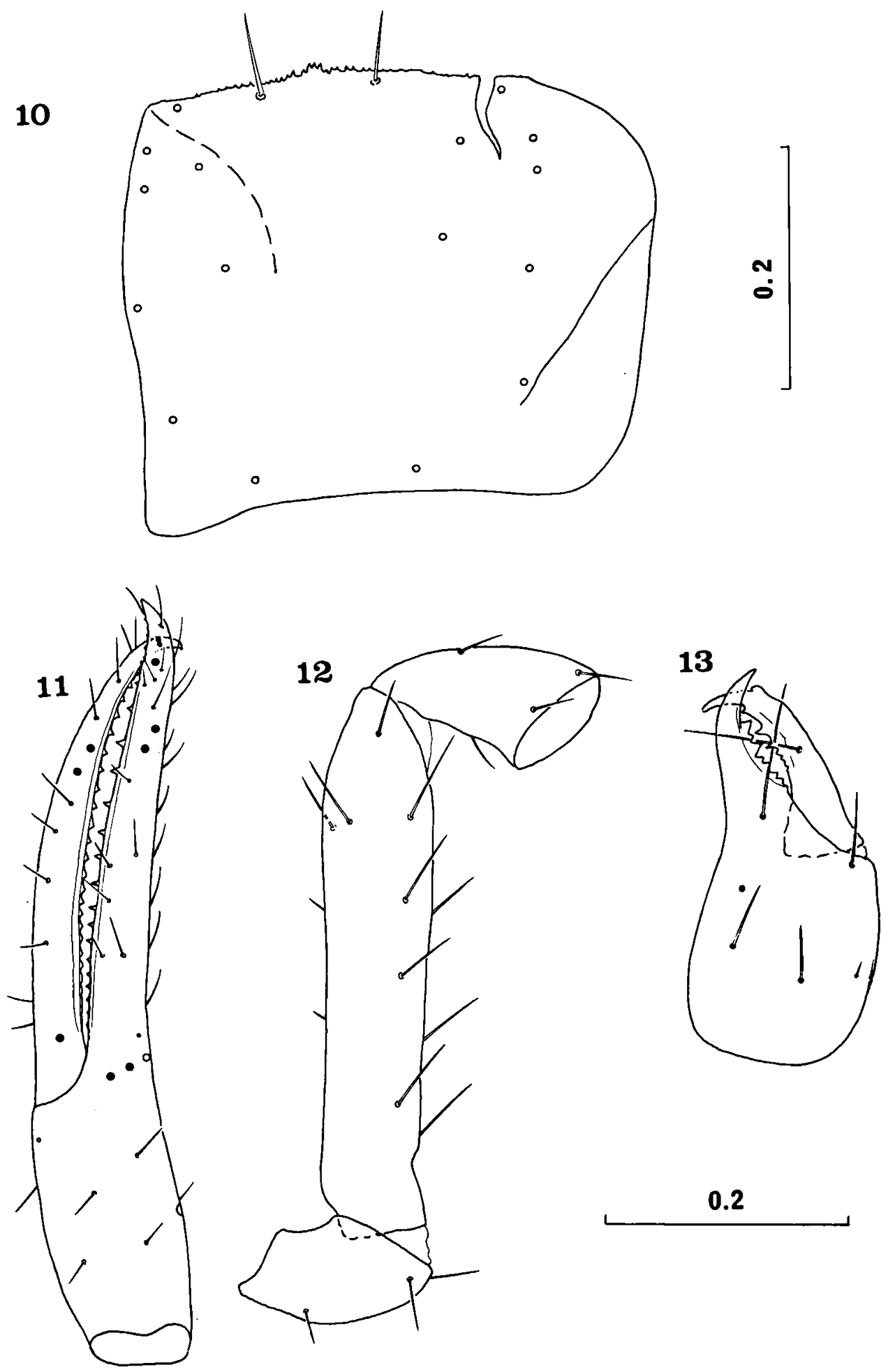

0.2

Figs. 10-13. Chthonius (Chthonius) monicae Boghean, 1989, tritonymph (FSB), from the Movile Cave, Romania: 10, carapace; 11 , pedipalpal chela; 12 , pedipalpal trochanter, femur, and tibia; 13 , chelicera. Scales in mm. 
Table I. Linear measurements (in $\mathrm{mm}$ ) and morphometric ratios in Chthonius $(C$.) monicae Boghean, from Romania. Abbreviations: trito. = tritonymph, $\mathrm{TS}=$ tactile seta.

\begin{tabular}{|c|c|c|c|}
\hline Character & १९ & $\sigma o$ & trito. \\
\hline \multicolumn{4}{|l|}{ Body } \\
\hline Length (1) & $1.48-2.63$ & $1.60-1.89$ & 1.09 \\
\hline \multicolumn{4}{|l|}{ Cephalothorax } \\
\hline Length (2) & $0.49-0.57$ & $0.47-0.55$ & 0.36 \\
\hline Breadth & $0.44-0.50$ & $0.43-0.46$ & 0.36 \\
\hline \multicolumn{4}{|l|}{ Abdomen } \\
\hline Length & $0.99-2.06$ & $1.10-1.37$ & 0.73 \\
\hline Breadth & $0.51-0.96$ & $0.58-0.75$ & 0.34 \\
\hline \multicolumn{4}{|l|}{ Chelicerae } \\
\hline Length (3) & $0.49-0.535$ & $0.425-0.48$ & 0.32 \\
\hline Breadth (4) & $0.21-0.23$ & $0.185-0.205$ & 0.15 \\
\hline Length of movable finger (5) & $0.26-0.28$ & $0.21-0.26$ & 0.185 \\
\hline Length of galea & 0.01 & 0.01 & 0.01 \\
\hline \multicolumn{4}{|l|}{ Pedipalps } \\
\hline Length with coxa (6) & $2.70-2.905$ & $2.515-2.72$ & 1.755 \\
\hline Ratio 6/1 & $1.08-1.82$ & $1.33-1.70$ & 1.61 \\
\hline Length of coxa & $0.47-0.51$ & $0.42-0.47$ & 0.34 \\
\hline Length of trochanter & $0.22-0.25$ & $0.205-0.22$ & 0.15 \\
\hline Length of femur (7) & $0.68-0.75$ & $0.63-0.73$ & 0.44 \\
\hline Breadth of femur (8) & $0.12-0.14$ & $0.11-0.12$ & 0.09 \\
\hline Ratio $7 / 8$ & $5.21-5.83$ & $5.46-6.08$ & 4.89 \\
\hline Ratio $7 / 2$ & $1.28-1.49$ & $1.145-1.47$ & 1.22 \\
\hline Length of tibia (9) & $0.25-0.29$ & $0.25-0.28$ & 0.18 \\
\hline Breadth of tibia (10) & $0.14-0.15$ & $0.13-0.15$ & 0.12 \\
\hline Ratio $9 / 10$ & $1.785-2.07$ & $1.785-2.00$ & 1.50 \\
\hline Length of chela (11) & $1.04-1.165$ & $0.945-1.02$ & 0.645 \\
\hline Breadth of chela (12) & $0.16-0.18$ & $0.15-0.17$ & 0.12 \\
\hline Ratio $11 / 12$ & $6.11-6.875$ & $5.82-6.50$ & 5.375 \\
\hline Length of chelal palm (13) & $0.34-0.37$ & $0.29-0.32$ & 0.205 \\
\hline Ratio $13 / 12$ & $2.00-2.50$ & $1.705-2.10$ & 1.71 \\
\hline \multicolumn{4}{|l|}{ Length of chelal finger (14) } \\
\hline (fixed finger) & $0.68-0.795$ & $0.64-0.73$ & 0.44 \\
\hline \multicolumn{4}{|l|}{ Length of chelal finger } \\
\hline (movable finger) & $0.63-0.71$ & $0.59-0.69$ & 0.40 \\
\hline Ratio $14 / 13$ & $1.75-2.15$ & $2.03-2.52$ & 2.15 \\
\hline \multicolumn{4}{|l|}{ Leg IV } \\
\hline Total length & $2.265-2.44$ & $2.155-2.36$ & 1.475 \\
\hline Length of coxa & $0.27-0.30$ & $0.25-0.27$ & 0.205 \\
\hline Length of trochanter (15) & $0.205-0.25$ & $0.205-0.23$ & 0.16 \\
\hline Breadth of trochanter (16) & $0.13-0.15$ & $0.13-0.15$ & 0.10 \\
\hline Ratio $15 / 16$ & $1.53-1.71$ & $1.53-1.615$ & 1.60 \\
\hline Length of femur (17) & $0.62-0.70$ & $0.61-0.68$ & 0.40 \\
\hline Breadth of femur (18) & $0.205-0.25$ & $0.23-0.25$ & 0.16 \\
\hline Ratio $17 / 18$ & $2.58-3.17$ & $2.56-2.78$ & 2.50 \\
\hline Length of tibia (19) & $0.42-0.44$ & $0.39-0.45$ & 0.27 \\
\hline Breadth of tibia (20) & $0.09-0.10$ & $0.09-0.10$ & 0.08 \\
\hline Ratio $19 / 20$ & $4.25-4.67$ & $3.90-4.67$ & 3.375 \\
\hline Length of basitarsus (21) & $0.22-0.25$ & $0.21-0.25$ & 0.14 \\
\hline Breadth of basitarsus (22) & $0.065-0.08$ & $0.07-0.08$ & 0.06 \\
\hline Ratio $21 / 22$ & $2.93-3.69$ & $2.75-3.33$ & 2.33 \\
\hline Length of telotarsus (23) & $0.49-0.54$ & $0.44-0.535$ & 0.30 \\
\hline Breadth of telotarsus (24) & $0.04-0.05$ & $0.04-0.045$ & 0.04 \\
\hline Ratio $23 / 24$ & $9.80-13.00$ & $9.78-13.375$ & 7.50 \\
\hline TS ratio - tibia IV & $0.46-0.55$ & $0.46-0.52$ & 0.51 \\
\hline TS ratio - basitarsus IV & $0.36-0.42$ & $0.35-0.46$ & 0.38 \\
\hline TS ratio - telotarsus IV & $0.31-0.43$ & $0.35-0.39$ & 0.295 \\
\hline
\end{tabular}



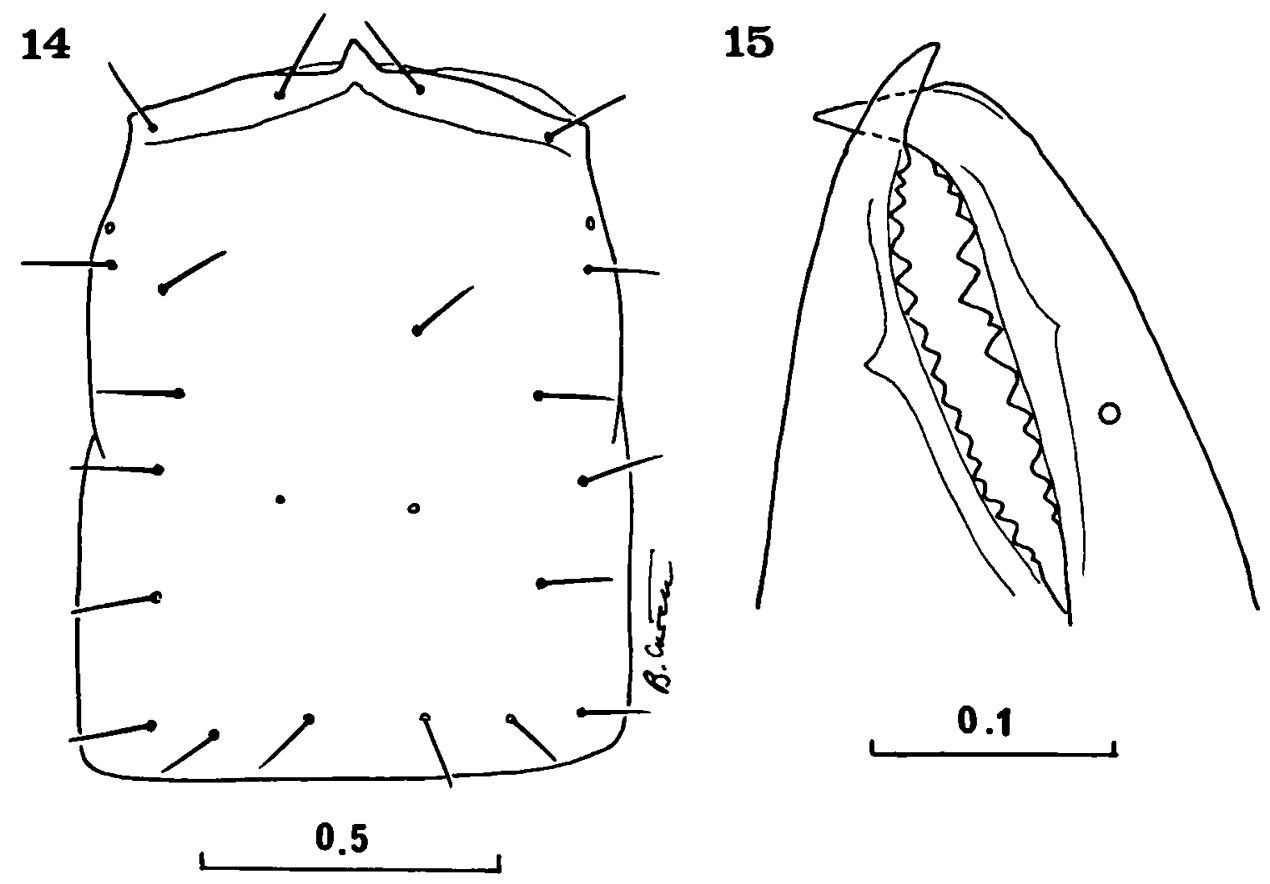

Figs. 14-15. Roncus ciobanmos n. sp., holotype $\odot$ (FSB), from the Movile Cave, Romania: 14, carapace; 15, cheliceral fingers. Scales in $\mathrm{mm}$.

Dobrogea (Dumitresco \& Orghidan, 1964) and the Dinaric Karst (Ćurčić, 1988a). Such variation in $C$. (C.) monicae is probably caused by a process of character reduction or differentiation in the underground habitat. The loss of pigment, eyes, and preocular microsetae support this assumption. It is evident that $C$. (C.) monicae is a true cave dweller, since both adult and tritonymph stages bear neither eyes nor eye spots. Furthermore, the presence in caves of a preadult stage (tritonymph) proves that the life cycle of this species can be completed in its cave environment.

NEOBISIIDAE Chamberlin, 1930

Roncus ciobanmos n. sp.

(Figs. 14-29, 38-42; Table II)

Etymology. - In Romanian mythology, Cioban Mos (= Zeu Moş) is the principal deity of shepherds (Vulcănescu, 1985).

Specimens examined. - Movile Cave, near Mangalia, southern
Dobrogea, Romania; holotype $\$$ and 1 paratype $९$ (FSB), 20 June 1992 (Serban M. Sarbu leg.); 1 paratype \& (MGAB), 18 June 1991; 1 paratype $\odot$ (MGAB), 20 June 1992; 1 paratype tritonymph (FSB), 18 June 1991; 1 paratype $Q$ and 1 paratype tritonymph (USNM), 15 Dec. 1991 (all same collector and locality).

Description. - Carapace longer than broad (Figs. 14, 23 \& 25; Table II). Epistome triangular, apically pointed (or slightly blunt) (Figs. 14, $23 \& 25$ ). Two weakly developed eye spots. Tapetum absent in female but present in tritonymph. Anterior row with 4 , ocular with 6 , median and intermedian rows with 6-10, and posterior row with 6 setae. Setal formula of carapace: $4-6,22-26$ (female). Tritonymphal setation: $4+1+6+4+2+6=23$.

Tergite I with 6 setae, tergite II with 7 setae in tritonymph and 8 or 9 in adults, tergite III with 8 or 9 setae in tritonymph and 10 or 11 in females. Subsequent tergites (IV-X) each with 9-11 setae in tritonymph and 10-12 in females. Male genital area unknown. Female genital area: sternite II with 9-12 small setae (in form of two barely distinguishable groups, close to each other), sternite III with 12-14 setae and 3 microsetae along each stigma. 


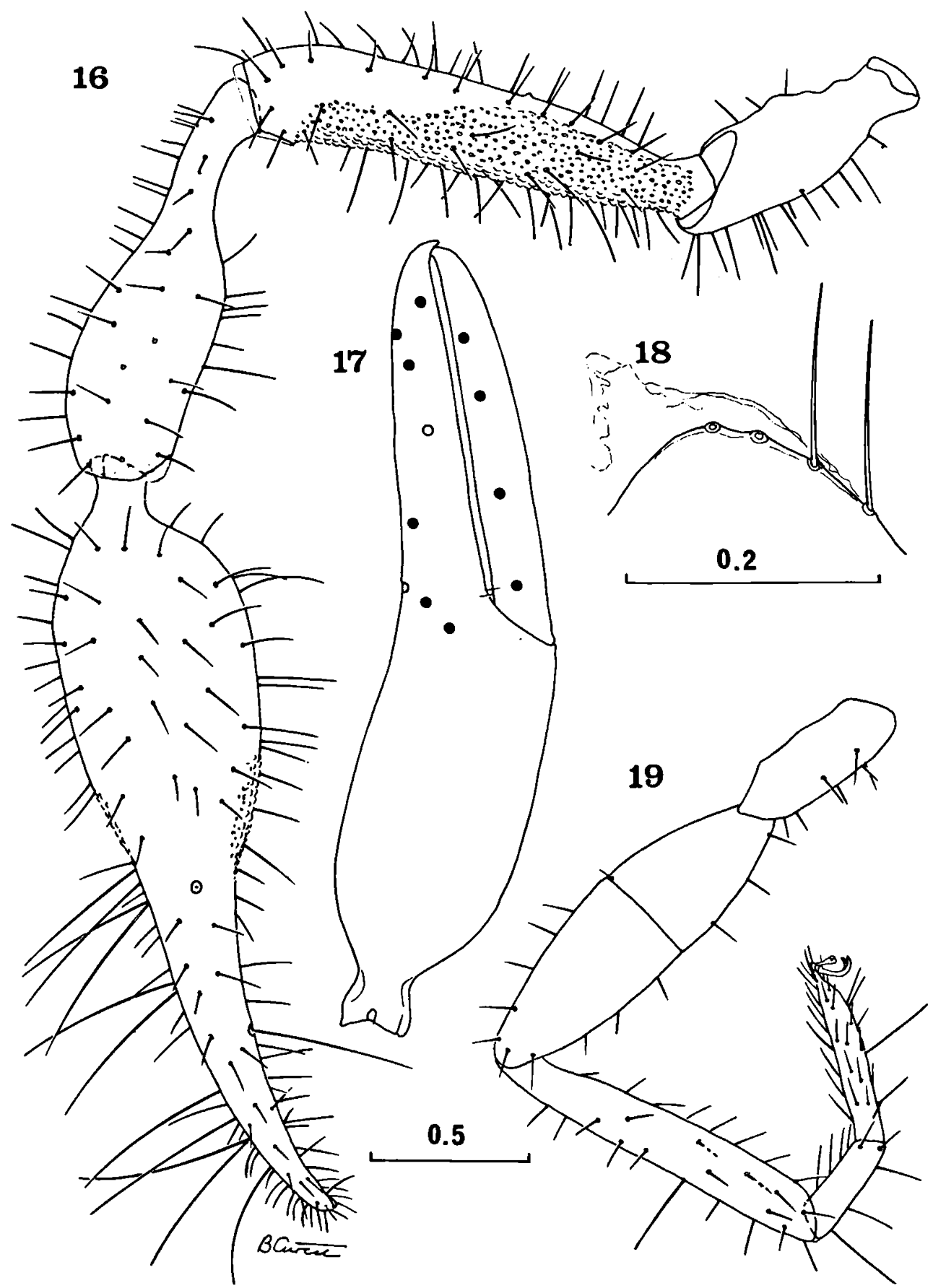

Figs. 16-19. Roncus ciobanmos n. sp., holotype $\$$ (FSB), from the Movile Cave, Romania: 16, pedipalp; 17, pedipalpal chela 18, apex of pedipalpal coxa; 19, leg IV. Scales in $\mathrm{mm}$.

Tritonymph: sternite II with 2 or 3 setae, and sternite III with 6 or 7 setae. Sternites $V-X$ each with 11-13 setae in tritonymph and 12-15 marginal setae in females. Setae on sternites $\mathrm{V}-\mathrm{X}$ arranged in transverse rows; anterior and median setae lacking.

Galea as a low hyaline convexity (Figs. 15, $21 \&$ 28). Cheliceral palm with 6 setae, movable finger with only 1 seta. Flagellum with 1 short proximal 


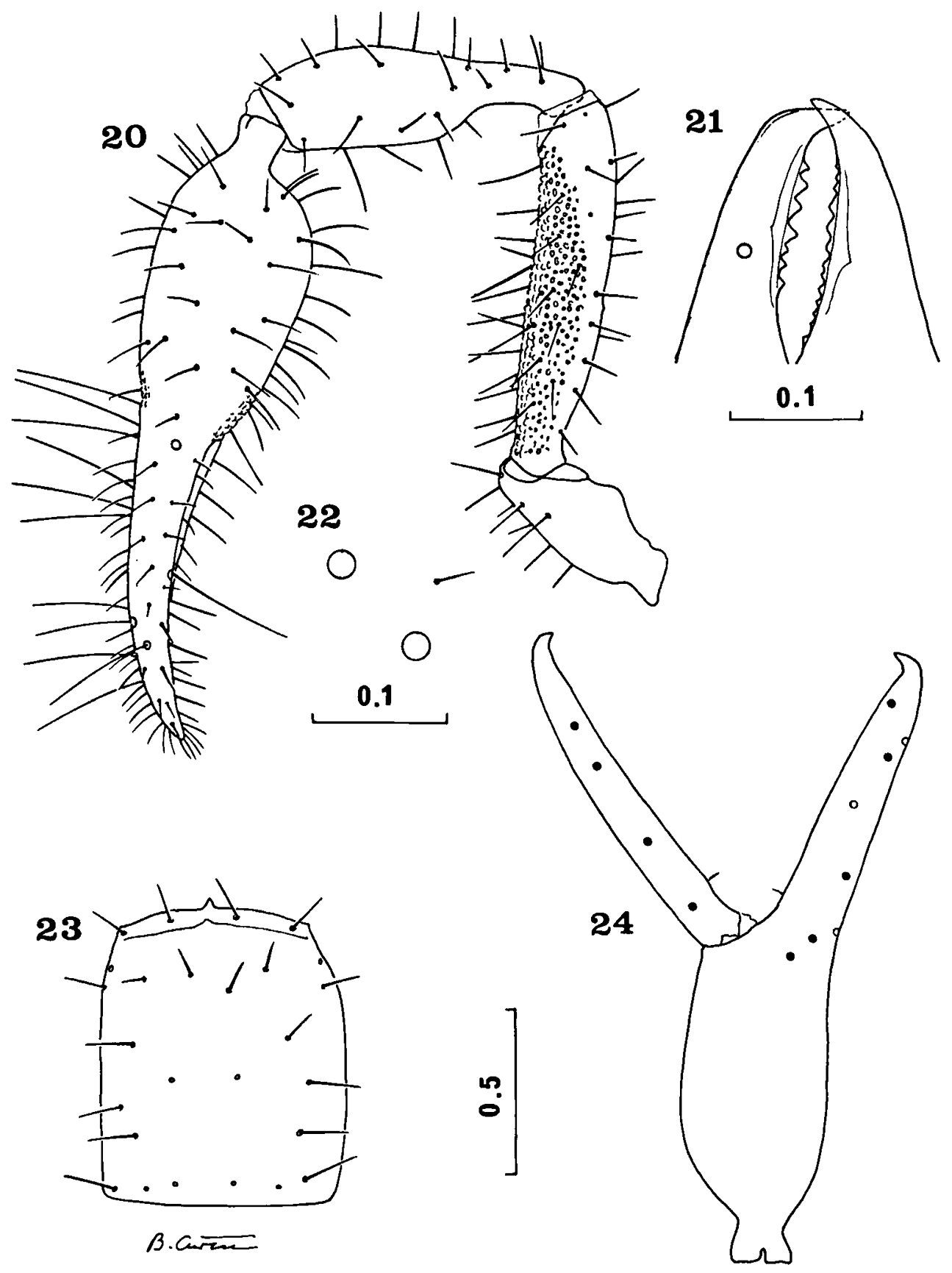

Figs. 20-24. Roncus ciobanmos n. sp., paratype $\$$ (FSB), from the Movile Cave, Romania: 20, pedipalp; 21, cheliceral fingers; 22, microseta distal to $e b$-es $b ; 23$, carapace; 24 , pedipalpal chela. Scales in $\mathrm{mm}$.

blade and 7 longer blades distally, characteristic of the genus Roncus. All blades pinnate along their anterior margins.

Apex of pedipalpal coxa with 3 setae in trito- nymph and 3 or 4 long ones in females (Figs. 18, 29). Pedipalpal trochanter with a small lateral tubercle and 1-4 small interior setae (no stout chaetae!); femur with a small exterolateral tubercle, and 


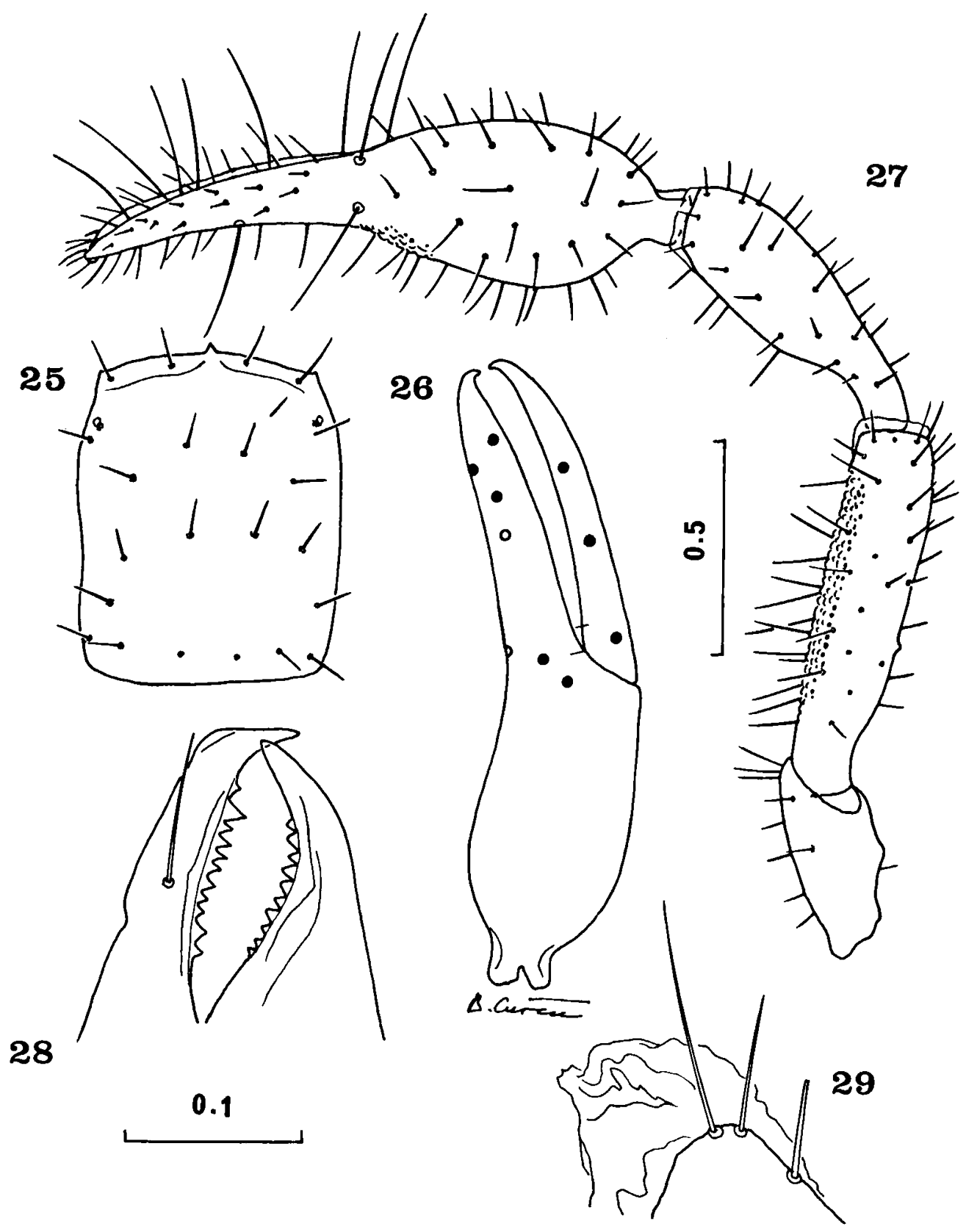

Figs. 25-29. Roncus ciobanmos n. sp., paratype tritonymph (FSB), from the Movile Cave, Romania: 25, carapace; 26, pedipalpal chela; 27, pedipalp; 28 , cheliceral fingers; 29 , apex of pedipalpal coxa. Scales in mm.

with some interior and lateral granulations (Figs. 16, 20 \& 27). Tibia smooth (Figs. 38-42). Chelal palm with some interolateral granulations and rare, inconspicuous and flattened tubercles on its exterolateral side (these tubercles are absent in trito- nymph) (Figs. 16, $20 \& 27$ ). Single tiny tubercle present on laterodistal side of chelal palm. Group of microsetae proximal to trichobothria $e b$ and $e s b$ not developed (Fig. 22). Fixed chelal finger with 63-66 teeth in tritonymph and 85-110 in females; 
distal teeth asymmetrical, followed by small, closely set, and slightly retroconical teeth. Movable chelal finger with 62-64 teeth in tritonymph and 87-101 in females. Only distal teeth pointed and retroconical, others rounded or square-cusped. Sensillum between 14th and 17th tooth in tritonymph, and between 12 th and 26th tooth in female (either proximal to, distal to, or at the level of $s b$ ).

Chelal fingers equal to or longer than chelal palm and somewhat shorter than pedipalpal femur (Table II). Trichobothrial patterns (Figs. 17, 24 \& 26): $s b$ slightly closer to $b$ than to $s t, s t$ closer to $t$ than to $s b$; ist slightly closer to est than to isb (Figs. 17, 24 \& 26).

Tibia IV, basitarsus IV, and telotarsus IV each with a long tactile seta (Fig. 19). Only in one paratype female, the right telotarsus IV carries an additional subproximal tactile seta (somewhat shorter than other tactile setae); the setation of the left telotarsus IV is here apparently normal. Morphometric ratios and linear measurements are presented in Table II.

Distribution. - Endemic species of southern Dobrogea, Romania (Movile Cave).

Relationships of $R$. ciobanmos and other species. $R$. ciobanmos is related to four eastern Serbian (Yugoslav) cavernicolous species: $R$. talason Curčić, Lee \& Makarov, 1993, R. timacensis Curčić, 1981, $R$. remesianensis Ćurčić, 1981, and $R$. pljakici Ćurčić, 1973.

The new species is distinct from $R$. talason, its phenetically most similar species, in the pedipalpal femur length to breadth ratio (3.975-4.83 vs. 5.20), the pedipalpal chela length to breadth ratio (3.89-4.71 vs. 4.85$)$, the granulations on the exterolateral surface of the chelal palm (present vs. absent), the number of teeth on the movable chelal finger (87-101 vs. 83), the form of the pedipalpal articles, and in body size (greater vs. smaller).

$R$. ciobanmos and $R$. timacensis are distinct in many important aspects, such as the relative position of ist (equidistant from est and isb vs. closer to est than to isb), the granulations on the exterolateral surface of the chelal palm (present vs. absent), the eye spots (present vs. absent), the form of the pedipalpal podomeres (less elongate vs. more elongate), and the body size (greater vs. smaller).

$R$. ciobanmos and $R$. remesianensis exhibit considerable differences in the eye spots (present vs. absent), in the granulations on the exterolateral surface of the chelal palm (present vs. absent), in the number of teeth of the movable chelal finger (87-101 vs. $80-86)$, in the pedipalpal tibia length to breadth ratio $(3.18-3.38$ vs. $2.65-3.03)$, in the pedipalpal chela length to breadth ratio (4.23-4.71 vs. $3.85-4.11$ ), and in body size (greater vs. smaller).

The troglobitic $R$. ciobanmos and $R$. pljakici are easily distinguished by the granulations on the exterolateral side of the chelal palm (present vs. absent), by the relative position of ist (equidistant from est and isb vs. closer to est than to isb), by the pedipalpal length $(5.365-7.58 \mathrm{~mm}$ vs. $5.14 \mathrm{~mm})$, by the pedipalpal tibia length $(0.97-1.32 \mathrm{~mm}$ vs. $0.87 \mathrm{~mm}$ ), by the pedipalpal tibia length to breadth ratio (3.18-3.38 vs. 2.64$)$, by the pedipalpal chela length to breadth ratio ( $4.23-4.71$ vs. 4.09$)$, by the form of the pedipalpal podomeres (more elongate vs. less elongate), and by the body size (greater vs. smaller).

$R$. ciobanmos is easily distinguished from the other sympatric species, $R$. dragobete, in the majority of linear measurements and morphometric ratios: carapace length $(0.95-1.23 \mathrm{~mm}$ vs. 0.59 $\mathrm{mm})$, cheliceral length $(0.54-0.70 \mathrm{~mm}$ vs. 0.38 $\mathrm{mm})$, pedipalpal femur length $(1.11-1.60 \mathrm{~mm}$ vs. $0.65 \mathrm{~mm})$, pedipalpal femur breadth $(0.24-0.36$ mm vs. $0.18 \mathrm{~mm})$, pedipalpal tibia length (0.97$1.32 \mathrm{~mm}$ vs. $0.51 \mathrm{~mm}$ ), pedipalpal chela length (1.985-2.92 mm vs. $1.16 \mathrm{~mm}$ ), femur IV length (1.01-1.21 mm vs. $0.56 \mathrm{~mm}$ ), pedipalpal femur length to breadth ratio (4.44-4.83 vs. 3.61$)$, pedipalpal tibia length to breadth ratio $(3.18-3.38$ vs. 2.22), and femur IV length to breadth ratio (3.394.04 vs. 3.03 ). In addition, $R$. ciobanmos differs from $R$. dragobete in the number of teeth on the fixed (85-110 vs. 54) and movable chelal fingers (87-101 vs. 52), in the granulations on the pedipalpal tibia (absent vs. present), in the form of the pedipalpal podomeres (elongate vs. stout), and in body size (greater vs. smaller).

There is pronounced individual variation of a 
Table II. Linear measurements (in $\mathrm{mm}$ ) and morphometric ratios in Roncus ciobanmos n. sp., R. dragobete $\mathrm{n} . \mathrm{sp}$. , and Neobisium (N.) biharicum Beier, from Romania. Abbreviations: trito. = tritonymph, TS = tactile seta.

\begin{tabular}{|c|c|c|c|c|}
\hline \multirow[t]{2}{*}{ Character } & \multicolumn{2}{|c|}{ ciobanmos } & \multirow{2}{*}{$\begin{array}{l}\text { dragobete } \\
q\end{array}$} & \multirow{2}{*}{$\begin{array}{l}\text { biharicum } \\
\text { ㅇ }\end{array}$} \\
\hline & १ ९ & trito. & & \\
\hline \multicolumn{5}{|l|}{ Body } \\
\hline Length (1) & $2.93-3.84$ & $2.31-3.27$ & 1.89 & 5.21 \\
\hline \multicolumn{5}{|l|}{ Cephalothorax } \\
\hline Length (2) & $0.95-1.23$ & 0.73 & 0.59 & 1.23 \\
\hline Breadth & $0.74-0.94$ & $0.60-0.66$ & 0.56 & 1.32 \\
\hline \multicolumn{5}{|l|}{ Abdomen } \\
\hline Length & $1.85-2.61$ & $1.58-2.54$ & 1.30 & 3.98 \\
\hline Breadth & $0.96-1.20$ & 0.89 & 0.72 & 1.85 \\
\hline \multicolumn{5}{|l|}{ Chelicerae } \\
\hline Length (3) & $0.54-0.70$ & $0.435-0.44$ & 0.38 & 0.905 \\
\hline Breadth (4) & $0.26-0.35$ & 0.23 & 0.20 & 0.46 \\
\hline Length of movable finger (5) & $0.36-0.48$ & $0.36-0.37$ & 0.25 & 0.59 \\
\hline Length of galea & 0.01 & 0.01 & - & 0.05 \\
\hline \multicolumn{5}{|l|}{ Pedipalps } \\
\hline Length with coxa (6) & $5.365-7.58$ & $3.895-4.06$ & 3.14 & 9.13 \\
\hline Ratio 6/1 & $1.54-2.22$ & $1.19-1.76$ & 1.66 & 1.75 \\
\hline Length of coxa & $0.66-0.89$ & $0.57-0.59$ & 0.44 & 1.18 \\
\hline Length of trochanter & $0.63-0.85$ & $0.43-0.48$ & 0.38 & 0.92 \\
\hline Length of femur (7) & $1.11-1.60$ & $0.795-0.84$ & 0.65 & 2.02 \\
\hline Breadth of femur (8) & $0.24-0.36$ & $0.20-0.205$ & 0.18 & 0.41 \\
\hline Ratio $7 / 8$ & $4.44-4.83$ & $3.975-4.10$ & 3.61 & 4.93 \\
\hline Ratio $7 / 2$ & $1.17-1.35$ & $1.09-1.15$ & 1.10 & 1.64 \\
\hline Length of tibia (9) & $0.97-1.32$ & $0.65-0.71$ & 0.51 & 1.43 \\
\hline Breadth of tibia (10) & $0.305-0.41$ & $0.23-0.24$ & 0.23 & 0.48 \\
\hline Ratio $9 / 10$ & $3.18-3.38$ & $2.83-2.96$ & 2.22 & 2.98 \\
\hline Length of chela (11) & $1.985-2.92$ & $1.42-1.44$ & 1.16 & 3.58 \\
\hline Breadth of chela (12) & $0.46-0.62$ & $0.34-0.37$ & 0.32 & 0.85 \\
\hline Ratio $11 / 12$ & $4.23-4.71$ & $3.89-4.18$ & 3.625 & 4.21 \\
\hline Length of chelal palm (13) & $0.95-1.34$ & 0.71 & 0.54 & 1.56 \\
\hline Ratio $13 / 12$ & $2.065-2.16$ & $1.92-2.09$ & 1.69 & 1.835 \\
\hline Length of chelal finger (14) & $1.035-1.58$ & $0.71-0.73$ & 0.62 & 2.02 \\
\hline Ratio $14 / 13$ & $1.00-1.18$ & $1.00-1.03$ & 1.15 & 1.29 \\
\hline \multicolumn{5}{|l|}{ Leg IV } \\
\hline Total length & $3.65-4.555$ & $2.645-2.73$ & 2.225 & 6.61 \\
\hline Length of coxa & $0.46-0.59$ & $0.40-0.425$ & 0.35 & 0.89 \\
\hline Length of trochanter (15) & $0.43-0.555$ & $0.31-0.34$ & 0.32 & 0.78 \\
\hline Breadth of trochanter (16) & $0.17-0.20$ & 0.14 & 0.14 & 0.29 \\
\hline Ratio $15 / 16$ & $2.31-2.775$ & $2.21-2.43$ & 2.285 & 2.69 \\
\hline Length of femur (17) & $1.01-1.21$ & $0.71-0.73$ & 0.56 & 1.81 \\
\hline Breadth of femur (18) & $0.25-0.35$ & $0.19-0.205$ & 0.185 & 0.41 \\
\hline Ratio $17 / 18$ & $3.39-4.04$ & $3.56-3.74$ & 3.03 & 4.41 \\
\hline Length of tibia (19) & $0.93-1.19$ & $0.61-0.64$ & 0.49 & 1.45 \\
\hline Breadth of tibia (20) & $0.11-0.18$ & 0.11 & 0.09 & 0.21 \\
\hline Ratio $19 / 20$ & $6.44-7.285$ & $5.545-5.82$ & 5.44 & 6.90 \\
\hline Length of basitarsus (21) & $0.33-0.41$ & $0.23-0.24$ & 0.185 & 0.69 \\
\hline Breadth of basitarsus (22) & $0.09-0.12$ & $0.08-0.09$ & 0.075 & 0.18 \\
\hline Ratio $21 / 22$ & $3.30-3.45$ & $2.555-3.00$ & 2.47 & 3.83 \\
\hline Length of telotarsus (23) & $0.49-0.61$ & $0.36-0.38$ & 0.32 & 0.99 \\
\hline Breadth of telotarsus (24) & $0.08-0.10$ & $0.08-0.09$ & 0.075 & 0.13 \\
\hline Ratio $23 / 24$ & $5.555-6.125$ & $4.22-4.50$ & 4.27 & 7.615 \\
\hline TS ratio - tibia IV & $0.56-0.62$ & $0.54-0.55$ & 0.58 & 0.36 \\
\hline TS ratio - basitarsus IV & $0.155-0.24$ & $0.22-0.26$ & 0.26 & 0.11 \\
\hline \multirow[t]{2}{*}{ TS ratio - telotarsus IV } & $0.37-0.48$ & $0.39-0.46$ & 0.38 & 0.19 \\
\hline & - & - & - & 0.57 \\
\hline
\end{tabular}


number of morphological features in $R$. ciobanmos, viz.: carapace setation (number and relative position of carapace setae), setation of the apex of the pedipalpal coxa, number of chelal teeth, and, particularly, form and size of pedipalpal articles (Figs. 16, 20 \& 38-42) and body size (Table II). In our opinion, one of the main causes of this variation should be sought among the factors affecting the process of adaptation of $R$. ciobanmos to the subterranean environment. Similar phenomena have been observed in a number of pseudoscorpion species inhabiting caves of the Dinaric Karst (Ćurčić, 1988a) and elsewhere (pers. comm.: Mahnert to Curčić, 23 November 1992).

$R$. ciobanmos is closely related to a number of cavernicolous species ( $R$. talason, $R$. pljakici, $R$. timacensis, and $R$. remesianensis), from eastern and southeastern Serbia, Yugoslavia. All these species are considered either descendants of the Balkanic epigean species $R$. parablothroides Hadži, 1937 , or having a common origin with this species (Ćurčić, 1991). The finding of $R$. ciobanmos is thus further proof of the endemic differentiation or pronounced radiation of $R$. parablothroides-related species, by means of intensive colonization of cave habitats in different karstic areas of the Balkans and adjoining regions.

It is suggested that the ancestral population of $R$. ciobanmos might have populated underground habitats well before the formation of the Movile Cave (perhaps in the form of a "lithoclassicolous" population; Dumitresco \& Orghidan, 1964), or at the beginning of the cave formation, i.e. some 5.5 to 5.2 million years ago (Lascu, 1989; Sarbu \& Popa, 1992).

$R$. ciobanmos probably colonized its type locality recently; the presence of eye spots in both adult and subadult stages, and the presence of tapetum in the tritonymph stage support this assumption. Nevertheless, this species is a true troglobite and its life cycle is fully established in the underground habitat (as its cave-adapted tritonymph lives in the cave as well).
Roncus dragobete n. sp.

(Figs. 30-37, 43; Table II)

Etymology. - In Romanian mythology, Dragobete is a wizard, the patron of joy and entertainment (Vulcănescu, 1985).

Specimen examined. - Holotype $\$$ (FSB), from the Movile Cave, near Mangalia, southern Dobrogea, Romania, 18 June 1991, Serban M. Sarbu leg.

Description. - Carapace with two tiny eye spots. Epistome triangular (Fig. 36). Setal formula: $4+$ $6+2+4+2+5=23$; the basic pattern is probably $4+6+2+4+2+6=24$ setae.

Tergites I-X bearing 6-8-9-10-10-1111-11-11-10 setae. Male genital area unknown. Female genital area: sternite II with 6 small median and posterior setae, in two barely distinguishable groups. Sternite III with 7 posterior setae and 2 or 3 suprastigmal microsetae on either side, sternite IV with 8 marginal setae and 2 or 3 microsetae along each stigma. Sternites $V-X$ each with $11-13$ setae. Setae on sternites VI-X arranged in transverse rows, without anterior and median setae.

Galea low and flattened (Figs. 31, 34). Cheliceral palm with 6 setae and movable finger with 1 seta. Flagellum with 1 short proximal blade and 7 longer blades distally, characteristic of the genus Roncus.

Apex of pedipalpal coxa with 2 or 3 long setae (Fig. 33). Pedipalpal trochanter with a small interior tubercle, femur with a small exterolateral tubercle and some interior and dorsal granulations (Figs. $30,43)$. Tibia tulip-shaped; surface with conspicuous distal granulations on interolateral side. Chelal palm with well-developed interolateral granulations and some weakly developed exterolateral ones (Fig. 30). Fixed chelal finger with 54 teeth; only distal teeth pointed and asymmetrical, other teeth small, closely set and retroconical. Movable chelal finger with 52 teeth; only distal teeth of this finger are pointed and retroconical, these are gradually merging into rounded or square-cusped teeth. Patch of microsetae proximal to $e b$ and $e s b$ absent (Fig. 35); single tubercle on laterodistal side of chelal palm present. Sensillum at level of 13th tooth, slightly proximal to $s b$. 


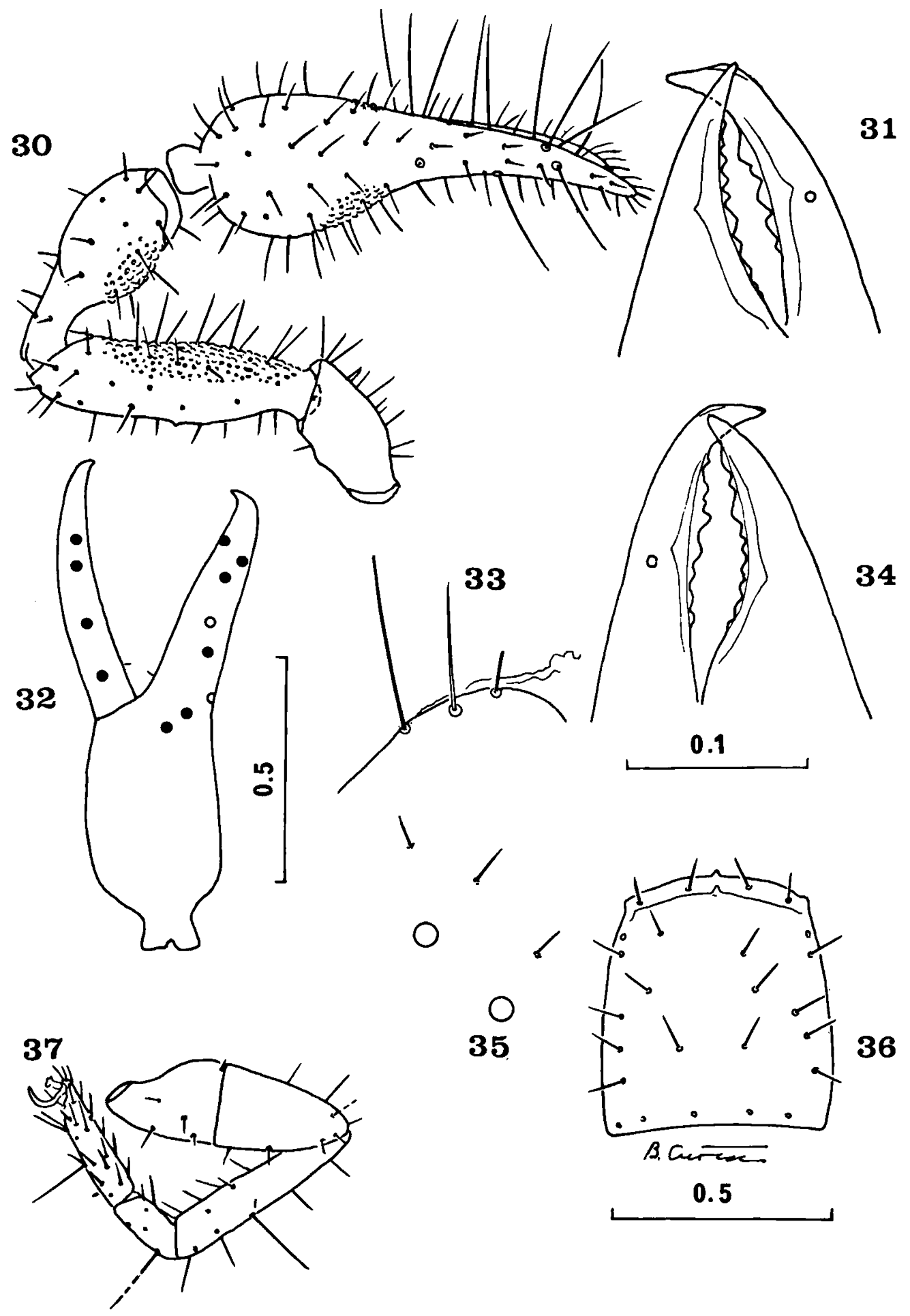

Figs. 30-37. Roncus dragobete n. sp., holotype o (FSB), from the Movile Cave, Romania: 30, pedipalp; 31, cheliceral fingers (right chelicera); 32, pedipalpal chela; 33, apex of pedipalpal coxa; 34, cheliceral fingers (left chelicera); 35 , microsetae distal to $e b-e s b$; 36, carapace; 37 , leg IV. Scales in $\mathrm{mm}$. 


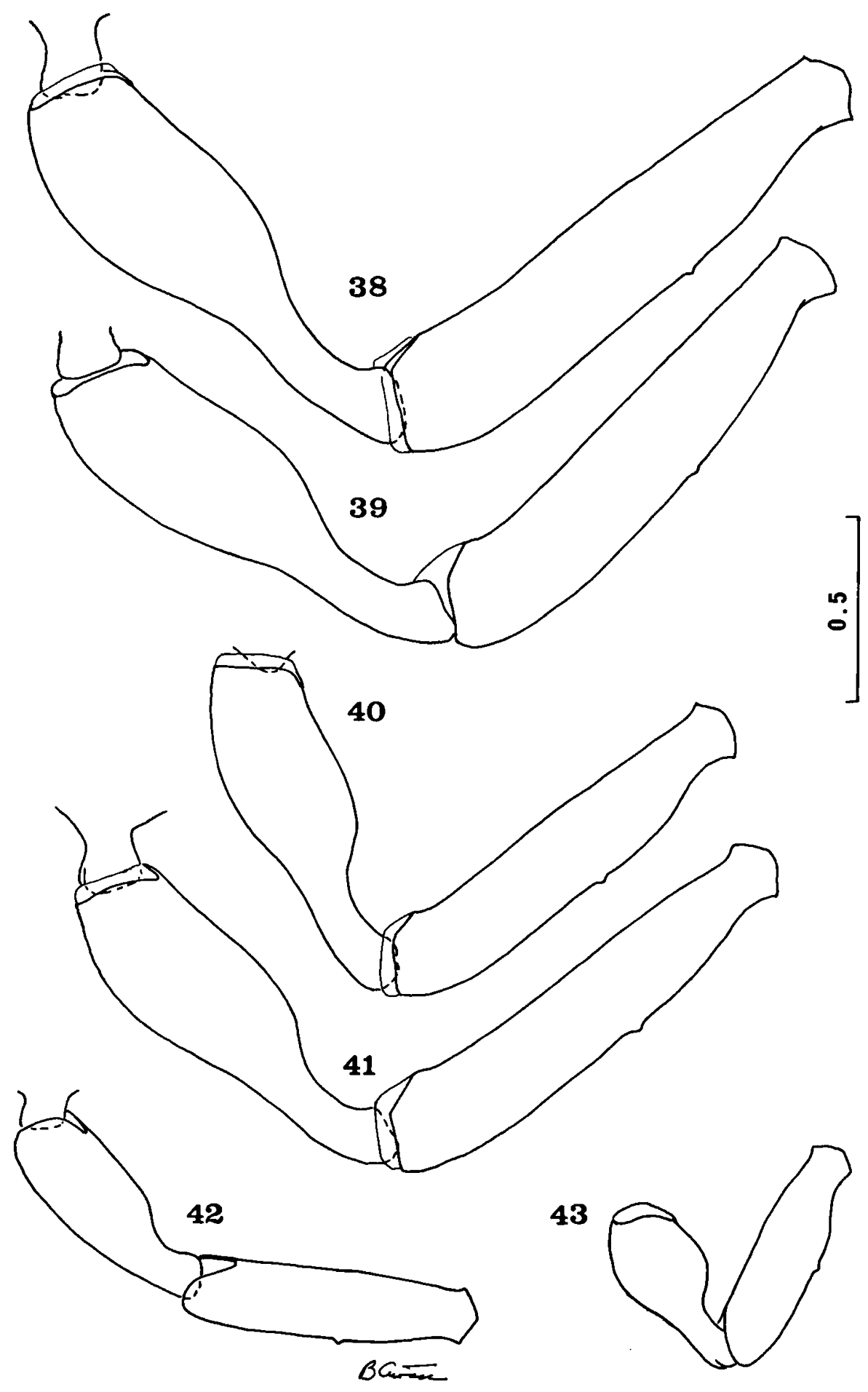

Figs. 38-43. Pedipalpal femora and tibiae (setae and granulation omitted): 38, $R$. ciobanmos n. sp., holotype $\odot$ (FSB); 39, $R$. ciobanmos n. sp., paratype $\odot$ (FSB); 40, $R$. ciobanmos n. sp., paratype $\odot$ (MGAB); 41, $R$. ciobanmos n. sp., paratype $\odot$ (USNM); $42, k$. ciobanmos $\mathrm{n}$. sp., paratype tritonymph (USNM); $43, R$. dragobete $\mathrm{n}$. sp., holotype $\odot$ (FSB). Scale in mm. 
Chelal palm ovate in dorsal view. Chelal finger slightly longer than chelal palm, but shorter than pedipalpal femur. Pedipalpal femur longer than carapace (Table II). Trichobothrial pattern (Fig. 32): ist closer to isb than to est; seta $s b$ equidistant from $s t$ and $b$; seta $s t$ closer to $t$ than to $s b$. Tibia IV, basitarsus IV, and telotarsus IV each with a single tactile seta (Fig. 37).

Morphometric ratios and linear measurements are presented in Table II.

Distribution. - Endemic species of southern Dobrogea, Romania (Movile Cave).

Relationships of $\boldsymbol{R}$. dragobete and other species. For comparison with $R$. ciobanmos, see p. 233.

The distinctions between $R$. dragobete and the epigean $R$. svarozici Ćurčić, 1992, inhabiting eastern Serbia, Yugoslavia, are manifested in the granulation of the pedipalpal femur (femur granulated along its interior surface vs. femur with interior and distal granulations only), in the granulations on the pedipalpal tibia (present vs. absent) and on the exterolateral side of the chelal palm (present vs. absent), in the pedipalpal femur length to carapace length ratio (femur longer than carapace vs. femur shorter than carapace), in the position of ist (closer to $i s b$ than to est vs. equidistant from $i s b$ and $e s t$ ), in the cheliceral length $(0.38 \mathrm{~mm}$ vs. $0.775-0.80$ $\mathrm{mm})$, in the pedipalpal length $(3.14 \mathrm{~mm}$ vs. $3.97-$ $3.985 \mathrm{~mm})$, in the pedipalpal femur length $(0.65$ $\mathrm{mm}$ vs. $0.78-0.79 \mathrm{~mm}$ ), in the pedipalpal femur length to breadth ratio (3.61 vs. $3.12-3.16)$, in the pedipalpal chela length to breadth ratio $(3.625 \mathrm{vs}$. 3.20-3.33), in the shape of the pedipalpal articles (less robust vs. more robust), and in body size (greater vs. smaller).

The distinctions between $R$. dragobete and its phenetically most similar species, the epigean $\boldsymbol{R}$. transsilvanicus, are manifested by the granulation of the pedipalpal femur (femur granulated along its interolateral surface vs. femur with interior and distal granulations only), by the granulations on the pedipalpal tibia (present vs. absent), by the chelal finger length to chelal palm length ratio (finger longer than chelal palm vs. finger as long as chelal palm; see also Beier, 1963), by the relative position of ist (closer to isb than to est vs. closer to est than to $i s b$, or equidistant from these; Beier, 1963), by the pedipalpal femur length to breadth ratio (3.61 vs. 4.10; Beier, 1963), by the pedipalpal tibia length to breadth ratio (2.22 vs. 2.50 ; Beier, 1963$)$, by the pedipalpal femur length $(0.65 \mathrm{~mm}$ vs. $1.02 \mathrm{~mm}$; Beier, 1963) and tibia length $(0.51$ vs. $0.85 \mathrm{~mm}$; Beier, 1963), by the chelal finger length to breadth ratio (3.625 vs. 3.30; Beier, 1963), and by the body size (smaller vs. greater).

It seems that $R$. dragobete colonized the cave habitat quite recently; this is supported by the presence of eye spots and by the relatively robust appendages in this species. In any case, it is probable that $R$. dragobete populated the underground milieu much later than its sympatric species $R$. ciobanmos.

Neobisium (Neobisium) biharicum Beier, 1939 (Figs. 44-51; Table II)

Specimen examined. - Movile Cave, near Mangalia, southern Dobrogea, Romania, 4 Jan. 1992, one 9 (FSB), Serban M. Sarbu leg.

Description. - Epistome triangular, with some apical chitinous points (Figs. 44, 47). Four well-developed eyes present, posterior eyes slightly less prominent than anterior eyes (Fig. 44). One or two microsetae in each preocular recess. Setal formula: $4+6+6+2+6=24$. Carapace reticulate.

Abdominal tergites I-X with 6-6-7-11-1010-10-10-11-10 setae. Male genital area unknown. Female genital area: sternite II with 11 $(6+5)$ setae [of these, $9(5+4)$ along posterior sternal border, and $2(1+1)$ anteriorly and medially]; setae on this sternite grouped into two barely distinguishable groups, each on either side of the midline. Sternite III with 24 dense and almost transversely arranged setae and 5 suprastigmatic microsetae on either side. Sternite IV with 3 or 4 microsetae along each stigma and 12 posterior setae. Sternites $V-X$ with 18-16-16-15-15-14 setae.

Galea prominent, crest-like (Fig. 45). Cheliceral palm with 7 setae, movable finger with 1 seta. Flagellum eight-bladed (Fig. 46); the two distalmost 

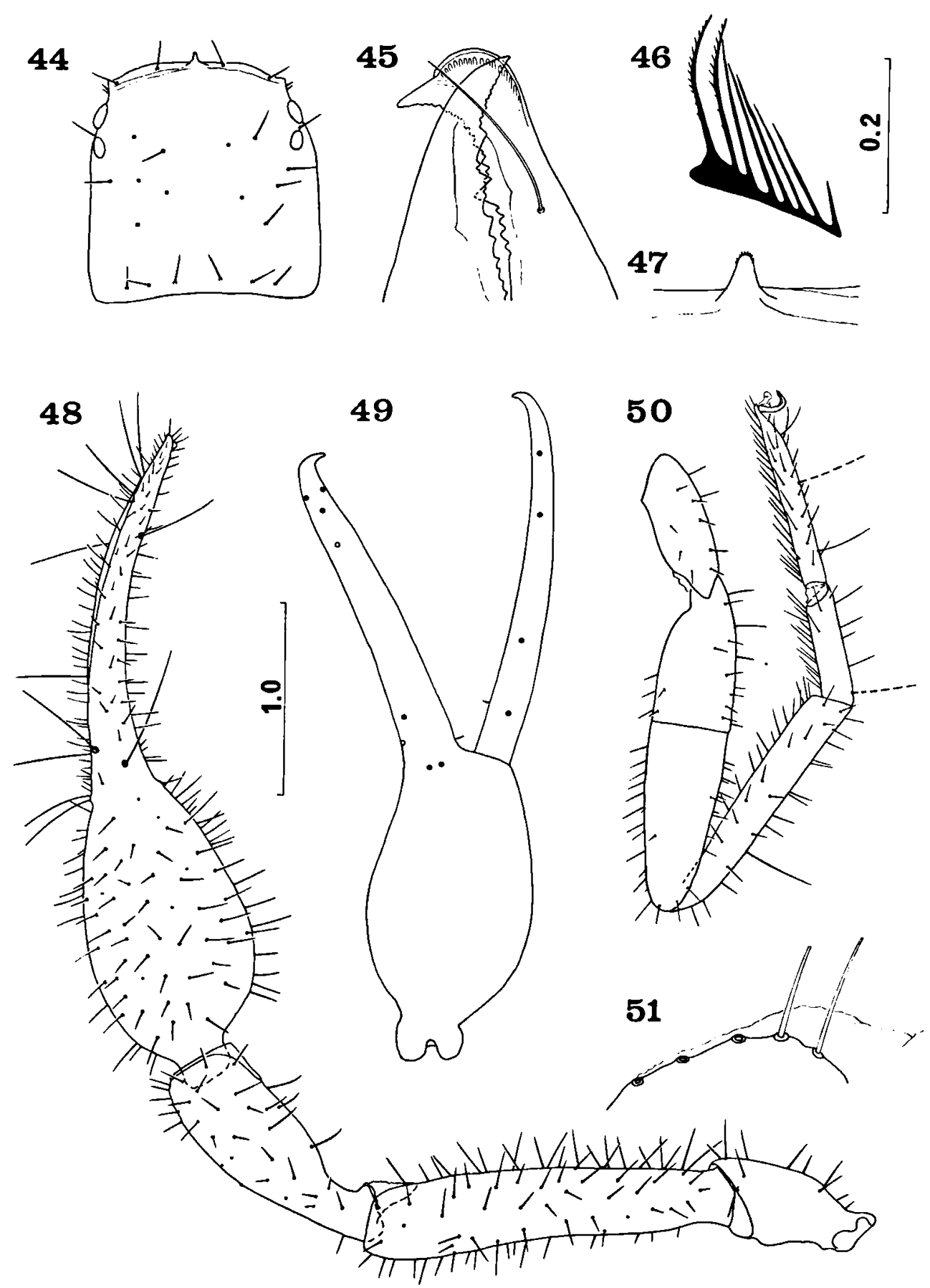

Figs. 44-51. Neobisium (N.) biharicum Beier, 1939, ९ (FSB), from the Movile Cave, Romania: 44, carapace; 45, cheliceral fingers; 46, flagellum; 47, epistome; 48, pedipalp; 49, pedipalpal chela; 50 , leg IV; 51 , apex of pedipalpal coxa. Scales in mm.

blades with some median denticulations which merge into distal pinnules, other blades smooth and diminishing in size from distal to proximal (characteristic of Neobisium).
Apex of pedipalpal coxa with 5 long setae (Fig. 51). Pedipalpal articles smooth (Fig. 48); trochanter with a small interior and lateral tubercle, chelal palm ovate (both dorsal and lateral views!). 
Fixed chelal finger with 105 closely-set teeth; distal teeth asymmetrical and pointed. Proximal teeth asymmetrical and slightly rounded apically; these eventually merge into small and rounded teeth. Movable chelal finger with 93 closely-set teeth; only distal teeth pointed and asymmetrical, others square-cusped and eventually rounded. Pedipalpal femur longer than carapace and shorter than chelal fingers, chelal fingers longer than chelal palm (Table II). Trichobothriotaxy as in Figs. 48, 49; ist closer to est than to isb.

Leg IV: tibia and basitarsus each with a long tactile seta, telotarsus with one subproximal $(0.34 \mathrm{~mm})$ and one subdistal tactile seta $(0.44 \mathrm{~mm})$ (Fig. 50$)$. For morphometric ratios and linear measurements, see Table II.

Distribution. - Probably endemic species of Romania; epigean and occasionally in caves.

Remarks. - The values of the linear measurements, morphometric ratios (Table II) and qualitative features of this specimen are within the variation range of these characters as stated by Beier (1963). Some minor distinctions are merely the result of intraspecific variation.

\section{Concluding remarks}

Immediately after its discovery in 1986, the Movile Cave in southern Dobrogea, Romania, drew the attention of numerous biologists. Surprisingly, most species inhabiting the cave were previously undescribed and are characterized by a high degree of troglomorphy (Sarbu \& Popa, 1992).

This underground habitat is inhabited by three cavernicolous pseudoscorpion species: Chthonius (C.) monicae (Chthoniidae), Roncus ciobanmos, $R$. dragobete, and by a surface and occasional cave dweller, Neobisium (N.) biharicum (Neobisiidae). All these species are considered endemic to Romania. It is evident that $C$. $(C$.) monicae is closely related to $C$. (C.) troglodites and $C$. (C.) cavophilus, both inhabiting some Bulgarian caves (Redikorzev, 1928; Hadži, 1939). On the other hand, $R$. ciobanmos is phenetically most similar to
$R$. talason from eastern Serbia, Yugoslavia, while $R$. dragobete is closely related to the epigean $R$. transsilvanicus from Romania. Finally, $N$. (N.) biharicum is related to some Balkan, Russian, and Georgian species [e.g.: N. (N.) labinskyi Beier, 1937; cf. Beier, 1963].

Interestingly enough, both $C$. (C.) monicae and $R$. ciobanmos are true troglobites, and their life cycle is fully established in their cave habitat; the same might hold true for $R$. dragobete, although this species has preserved its "epigean" appearance (presence of pigment and eye spots, relatively robust appendages, and comparatively short body setae). In addition, both $C$. (C.) monicae and $R$. ciobanmos show considerable variation in a number of qualitative and quantitative features, such as: pigmentation, presence/absence of preocular microsetae, number of posterior carapace setae, and setation of tergite I (C. monicae), as well as carapace setation, setation of the apex of the pedipalpal coxa, number of chelal teeth, form and size of pedipalpal articles, and some linear measurements and morphometric ratios ( $R$. ciobanmos).

It is known that some populations of cavedwelling arthropods that are apparently recent cave isolates show great variation in pigmentation, eye development, and some other morphological traits (Culver, 1982); such variation may be due to hybridization with the epigean ancestor after isolation in caves. Bearing this in mind, the statement "that the terrestrial troglobitic fauna of the Movile Cave became isolated from the surface at the end of the Miocene (5.5 to 5.2 million years ago)" (Lascu, 1989) is not sufficiently supported. Actually, part of the interest in regressive evolution arises from the fact that it may provide a clue to the amount of evolutionary time since the isolation in caves. Such a procedure is probably justified when regressive evolution is proceeded by neutral mutation or when the species are under similar selective regimes. In both cases the rate of evolution is constrained. If, on the other hand, the selective regimes differ (and the regressed characters are under selection; see e.g. Jones et al., 1992), for example in the degree of food limitation, regressive evolution is not even a crude measure of time (Culver, 1982; Curčić, 1988c). Therefore, much more remains to be learned 
about the evolution and ecology of the pseudoscorpions from the Movile Cave before we can judge the period in which $C$. (C.) monicae, $R$. ciobanmos, and $R$. dragobete have been isolated from the surface.

From the biogeographic point of view, it is clear that $C$. (C.) monicae, $R$. ciobanmos, and $R$. dragobete originated from the old Balkanic fauna of pseudoscorpions, while the epigean $N$. ( $N$.) biharicum is probably related both to the Balkanic and Caucasian forms. All these species are autochthones, and they probably represent relict forms. This supports the view that the Balkan Peninsula and adjoining regions represent the main refugium of a previously existing and varied fauna of Mediterranean pseudoscorpions (Ćurčić, 1988c).

\section{Acknowledgements}

We are grateful to Volker Mahnert for his useful comments on the taxonomy of Roncus.

Support for fieldwork was received from the "Beobanka" Belgrade, The Serbian Academy of Sciences and Arts, and the Serbian Ministry of Science and Technology (Grant 0324). This research was also supported by the National Geographic Society (Grant 4639-91), the Cave Research Foundation, the Department of Biological Sciences of the University of Cincinnati, and the "Emil Racoviţa" Speleological Institute in Bucharest.

\section{References}

Beier, M., 1963. Ordnung Pseudoscorpionidea (Afterskorpione). Bestimmungsbücher zur Bodenfauna Europas, 1: 1313 (Akademie-Verlag, Berlin).

Boghean, V., 1989. Sur un Pseudoscorpion cavernicole nouveau, Chthonius (C.) monicae n. sp. (Arachnida, Pseudoscorpionida, Chthoniidae). Misc. speol. Rom., 1: 77-83.

Cîrdei, F., F. Bulimar \& E. Malcoci, 1967. Contribuţii la studiul pseudoscorpionidelor (ord. Pseudoscorpionidea) din Moldova (Masivul Repedea). Anal. sţiinţ. Univ. “Al. I. Cuza”, Ser. nouă (2), Biol., 13: 237-242.

Culver, D.C., 1982. Cave life; evolution and ecology: $\mathrm{i}-\mathrm{ix}$, 1-189 (Harvard University Press, Cambridge/London).

Curčić, B.P.M., 1972a. Un Pseudoscorpion cavernicole nouveau pour la péninsule des Balkans, Chthonius (C.) bogovinae n. sp. (Chthoniidae, Pseudoscorpiones, Arachnida). Annls. Spéléol., 27: 341-350.

Curcić, B.P.M., 1972b. Deux nouveaux Pseudoscorpions habi- tant des localités souterraines de la Péninsule balkanique: Chthonius caecus iugoslavicus $n$. ssp. et Chthonius bogovinae latidentatus n. ssp. Glasn. Muz. Beogr., 27B: 125-142.

Curčić, B.P.M., 1988a. Cave-dwelling pseudoscorpions of the Dinaric Karst. Acad. Sci. Art. Slov., Cl. IV. Hist. Nat., Opera, Inst. Biol. Ioannis Hadzi, Ljubljana, 26(8): 1-191.

Curčić, B.P.M., 1988b. On the taxonomic status of Chthonius caecus iugoslavicus Curčić, 1972 (Chthoniidae, Pseudoscorpiones). Fragm. balcan., 14: 1-10.

Curčić, B.P.M., 1988c. Les Pseudoscorpions cavernicoles de la Yougoslavie: développement historique et implications biogéographiques. Revue Arachnol., 7: 163-174.

Curčić, B.P.M., 1991. A new species of the genus Roncus L. Koch, 1873 (Neobisiidae, Pseudoscorpiones) from East Serbia. Mém. Biospéol., 18: 165-169.

Ćurčić, B.P.M., R.N. Dimitrijević \& O.S. Karamata, 1992. A revision of some species of Roncus L. Koch (Neobisiidae, Pseudoscorpiones) from North America and South Europe. J. Arachnol., 20 (2): 114-128.

Dumitresco, M. \& T. Orghidan, 1964. Contribution à la connaissance des Pseudoscorpions de la Dobroudja. 1re note. Annls. Spéléol., 19: 599-630.

Gardini, G., 1983. Redescription of Roncus lubricus L. Koch, 1873, type-species of the genus Roncus L. Koch, 1873 (Pseudoscorpionida, Neobisiidae). Bull. Br. arachnol. Soc., 6: 7882.

Hadži, J., 1939. Pseudoskorpioniden aus Bulgarien. Izv. tsarsk. prirodonauch. Inst. Sofia, 13: 18-48.

Harvey, M., 1991. Catalogue of the Pseudoscorpionida: i-vi, 1-276 (Manchester University Press, Manchester \& New York).

Ionescu, M.A., 1936. Contribuţiuni la studiul Pseudoscorpionidelor din România. Bull. Soc. Nat. Rom., 8: 1-5.

Jones, R., D.C. Culver \& T.C. Kane, 1992. Are parallel morphologies of cave organisms the result of similar selection pressures? Evolution, 46 (2): 353-365.

Lascu, C., 1989. Paleogeographical and hydrogeological hypothesis regarding the origin of a peculiar cave fauna. Misc. Speol. Rom., 1: 13-18.

Redikorzev, V., 1928. Beiträge zur Kenntnis der Pseudoscorpionen-Fauna Bulgariens. Izv. tsarsk. prirodonauch. Inst. Sofia, 1: 118-141.

Sarbu, S., 1991. Contributions to the biological investigation of the "Movile Cave": the species composition and trophic structure of the cave community and the origin of the fauna. Mém. Biospéol., 18: 193-197.

Sarbu, S. \& R. Popa, 1992. A unique chemoautotrophically based cave ecosystem. In: A.L. Camacho (ed.), The natural history of biospeleology: 638-666 (Luis Gomez Arguero Publicaciones \& Museo Nacional de Ciencias Naturales, Madrid).

Vulcănescu, R., 1985. Mitologia română: 1-712 (Ed. Acad. Rep. Soc. România, Bucureşti).

Received: 5 February 1993 